\title{
REDATING IZTAPAN AND VALSEQUILLO, MEXICO
}

\author{
Mario Pichardo \\ 27 14th St, W, Minneapolis, Minnesota 55403, USA
}

\begin{abstract}
Recent radiocarbon dating of tephra sequences and biostratigraphic analysis in the Valley of Mexico and the Valley of Puebla, respectively, reveal that the FAD (first appearance date) for lanceolate Lerma/El Jobo points at Iztapan and Hueyatlaco archeological sites at about $14-16,000$ BP predates the Clovis culture FAD. A lack of interdisciplinary communication is responsible for the neglect of these sites for three decades.
\end{abstract}

\section{INTRODUCTION}

Recent radiocarbon dating of tephra sequences in the Valley of Mexico (Lozano-Garcia et al. 1993) and biostratigraphic analysis of paleontological and archeological stations in Valsequillo, Valley of Puebla (Pichardo 1999) indicate that the concept of equating the Paleoindian FAD (first appearance date) in North America with the appearance of the Clovis culture can now be definitely questioned. Lanceolate bifaces suggestive of pre-Clovis age have been reported from Sandia Cave, New Mexico (Haynes and Agogino 1986), and Lerma/El Jobo points have been found at Iztapan and Hueyatlaco, Mexico, and in South America (Pichardo 1999). But to the present this lanceolate pattern has been regarded as only a hypothetical ancestor of Clovis, which evolved as a regional adaptation to exploit the dwindling faunal resources of the terminal Pleistocene (cf. Stanford 1991).

\section{Santa Isabel Iztapan}

A review of mammoths excavated in the Valley of Mexico from 1952 to 1980 (Lorenzo and Mirambell 1986) approached their relative age from altimetry ("Catersian Coordinates" of Lorenzo) and concluded that the Gertrudis Sanchez mammoth (Pichardo et al. 1961) had not been dated (Lorenzo and Mirambell 1986:74). It was argued that describing this mammoth as the stratigraphically oldest cannot be supported by altimetry (Lorenzo and Mirambell 1986:77). The Bartolo Atepehuacan mammoth had approximately the same altimetry but was dated at $9670 \pm 400$ BP (M-776; Table 1).

Mexican prehistory has suffered from a lack of interdisciplinary communication (Pichardo 1997). The tephra studies of Mooser $(1961,1967)$ had been available for 20 years prior to the review cited above. Mooser and Rul (1961) dated the Gertrudis Sanchez mammoth as relatively the oldest by means of the overlying PWA (coarse pumice with andesite) tephra marker. It was older than the Tlalpan, Iztapan II, and Gasoduct mammoths (Mooser and Rul 1961; Figure 3)

But in 1967, Mooser dated peat under the PWA with an age of 14,700 $\pm 280 \mathrm{BP}$ (GX0878 number by Garcia-Barcena 1986; Lozano-Garcia et al. 1993 published his second date of 14,450 $\pm 100 \mathrm{BP}$, TX1914) and a chronostratigraphic tephra sequence was established. Lozano-Garcia et al. (1993: 336) have presented evidence that the PWA is more likely dated at about 16,500 BP. Consequently, and in spite of a similar altimetry, the Gertrudis Sanchez mammoth cannot be referred to the $9670 \pm$ $400 \mathrm{yr}$ date of the Atepehuacan mammoth (located about $5 \mathrm{~km}$ west) as implied by Lorenzo and Mirambell.

More importantly, the PWA dates the Lerma point associated with Iztapan mammoth II (Figure 1) and substantiates the typological considerations discussed above. It also places the Tepexpan hominid, a derived Walcolid, as already present in America between 14-16,000 BP (see Pichardo 1998, 1999). 
Table 1 Radiometric dates from Valley of Mexico and Valley of Puebla

\begin{tabular}{|c|c|c|c|}
\hline Material and location & Lab nr & Age (yr BP) & Method \\
\hline \multicolumn{4}{|l|}{ Valley of Mexico } \\
\hline San Bartolo Mammoth bone & M-776 & $9670 \pm 400$ & ${ }^{14} \mathrm{C}$ \\
\hline Organics from Chalco under & GX0878 & $14,700 \pm 280$ & ${ }^{14} \mathrm{C}$ \\
\hline PWA ash marker & & & \\
\hline (Same) & TX1914 & $14,450 \pm 100$ & ${ }^{14} \mathrm{C}$ \\
\hline Peat under UTP ash & GX0646 & $12,900 \pm 400$ & ${ }^{14} \mathrm{C}$ \\
\hline Santa Lucia mammoth I & - & $23,900 \pm 600$ & ${ }^{14} \mathrm{C}$ \\
\hline Santa Lucia mammoth II & - & $11,170 \pm 1650$ & Obsidian hydration \\
\hline \multicolumn{4}{|l|}{ Valley of Puebla } \\
\hline $\begin{array}{l}\text { Camel pelvis Hueyatlaco } \\
\text { level C }\end{array}$ & M-B-3 & $245,000 \pm 40,000$ & ${ }^{230} \mathrm{Th}$ \\
\hline Mammut molar, El Horno & M-B-8 & 280,000 & ${ }^{230} \mathrm{Th}$ \\
\hline Tetela Brown Mud & 73-SM-2 & $600,000 \pm 340,000$ & Fission track \\
\hline Hueyatlaco Ash & 73-SM-13,14 & $370,000 \pm 200,000$ & Fission track \\
\hline $\begin{array}{l}\text { Mollusk shell Caulapan unifacial } \\
\text { tool level }\end{array}$ & W-1895 & $21,850 \pm 850$ & ${ }^{14} \mathrm{C}$ \\
\hline $\begin{array}{l}\text { About same level proboscidean } \\
\text { vertebra }\end{array}$ & M-B-6 & $21,500 \pm 1500$ & $\begin{array}{l}{ }^{230} \mathrm{Th} \\
{ }^{231} \mathrm{Pr}\end{array}$ \\
\hline $\begin{array}{l}\text { Bone from Faunal Zone II near } \\
\text { Totimehuacan }\end{array}$ & KI-266 & $26,000 \pm 530$ & ${ }^{14} \mathrm{C}$ \\
\hline
\end{tabular}

To conclude, it is imperative that a re-examination of Tepexpan, Iztapan and Peñon stratigraphy be made to confirm the tephra sequence. This will also serve as a check on ${ }^{14} \mathrm{C}$ and obsidian hydration dates obtained from more recently found mammoth artifact associations such as Santa Lucia I $\left(23,900 \pm 600 \mathrm{BP}\right.$ by $\left.{ }^{14} \mathrm{C}\right)$ and $\mathrm{II}(11,170 \pm 1650 \mathrm{BP}$ by obsidian hydration $)$ cited by Lorenzo and Mirambell.

\section{Valsequillo}

In the Valley of Puebla, a tephra chronology has not been established because of the to-date undiscovered volcanic source of tephra found in the archeological sites with a comparable composition (Steen-McIntyre et al. 1981:11). The lapilli associated with bifacial tools, including a Lerma point, at Hueyatlaco unit $1 \mathrm{E}$ proved unsuitable for radiometric dating. A camel pelvis (M-B-3) from unit $\mathrm{C}$ was dated at $245,000 \pm 40,000 \mathrm{BP}\left({ }^{230} \mathrm{Th}\right.$; cf. Szabo et al. 1969; Tables 1,2). At the stratigraphically lower El Horno site a mastodon molar sample (M-B-8) was dated at $280,000 \mathrm{BP}\left({ }^{230} \mathrm{Th}\right)$.

These dates were rejected by prehistorians as inconsistent with the tool typology (Irwin-Williams 1981). It was argued that U-series dates have been subject to contamination, and that the fission-track dates of $600,000 \pm 340,000 \mathrm{BP}$ and 370,000 $\pm 200,000$ are in reverse stratigraphic order (cf. Steen-McIntyre et al. 1981; Table 2). Since this stalemate was the principal cause for the neglect and withdrawal from consideration of these sites by prehistorians, a different approach to the problem is required.

Most notably, the paleontology and biostratigraphy was never detailed after field work ended in 1966. Graham (1978), on the basis of the sample collected at the Smithsonian, considered the fauna to be Wisconsinian. But Guenther $(1968,1973)$ had noted the presence of species extinct by end of Illinoian and Sangamon time and that it was a heterochronous fauna, with diagenesis or redeposition 


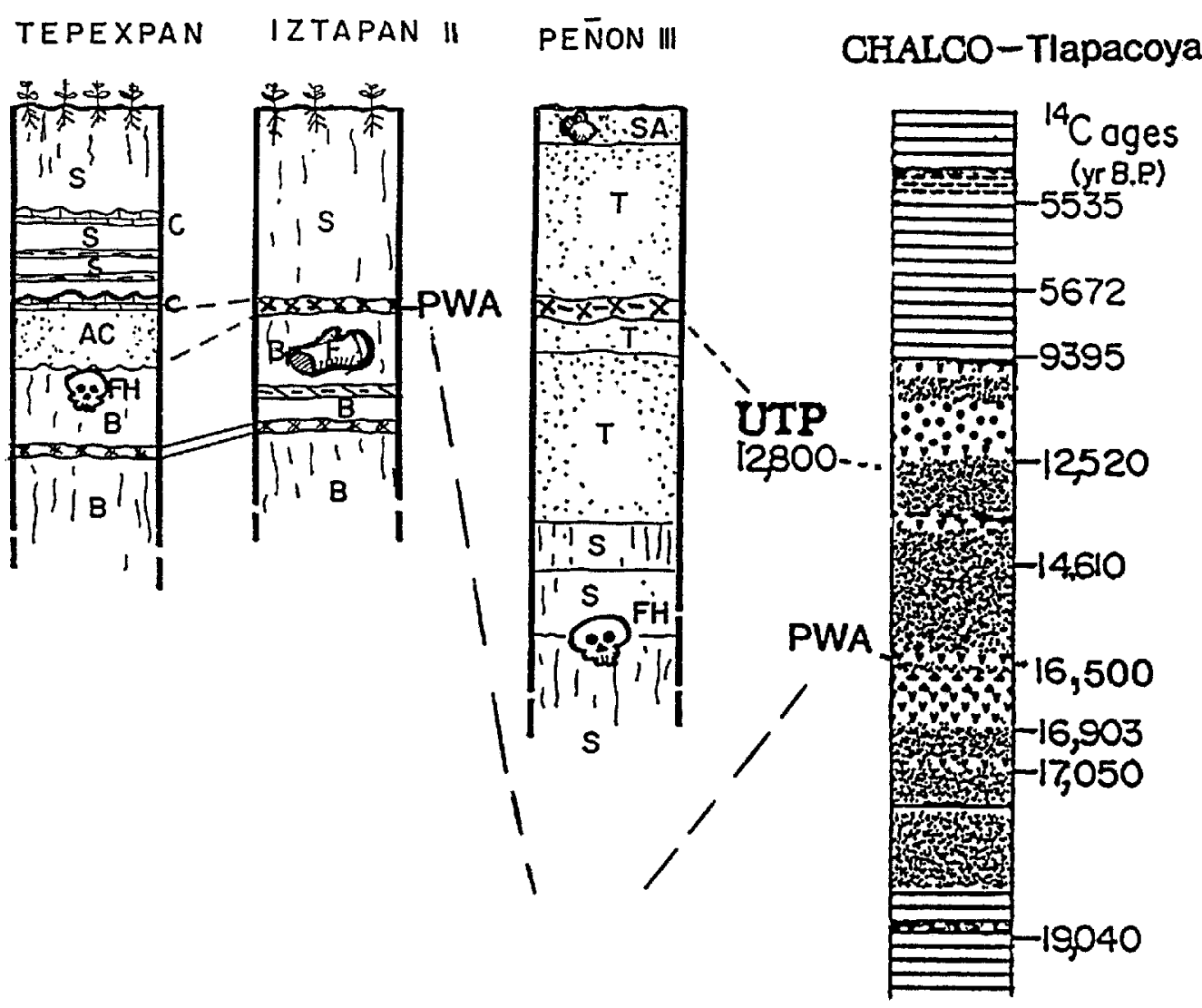

Figure 1 Left are three profiles from the Valley of Mexico from Mooser and Rul (1961, Figure 3). Right is Core 1 from Chalco after Lozano-Garcia et al. (1993, Figure 3). PWA (coarse pumice with andesite) ash marker. UTP (upper Toluca pumice). The 12,800 BP date comes from Core B, giving a range of 9920-12,900 BP for the UTP. See text for discussion.

of older fossils into younger levels at several sites. A point which has not been emphasized enough is that at the Caulapan locality the U-series dates agree with the ${ }^{14} \mathrm{C}$ dates. A unifacial tool was found at a level dated $21,850 \pm 850\left({ }^{14} \mathrm{C}\right.$ on shell) and a proboscidean vertebra (M-B-6) gave an average date of $21,500 \pm 1500\left({ }^{230} \mathrm{Th},{ }^{231} \mathrm{Pr}\right)$. These dates are comparable to Guenther's date (1973:14) for Faunal Zone II near Totimehuacan (26,000 $\pm 530 \mathrm{KI}-266)$. Further, the presence of the short-horned Bison antiquus (FAD about 30,000 BP) from the mid-Caulapan level establishes without question that there are at least two distinct chronofaunas (Pichardo 1999).

The dilemma to be resolved is that at Hueyatlaco Malde, traced from the south the superposition of an alluvial layer (sand grading to clay; Figure 2) cutting the archeological beds. This superposed bed in turn is overlain by volcanic sediments dated by the "Fission Track" method-in excess of 300,000 yr (Hueyatlaco Ash), and 600,000 yr (Tetela Brown Mud), but in reverse order. Figure 2 compares the section at the Hueyatlaco archeological site with Bunde' s (1973) loc. 103, $20 \mathrm{~m}$ south, illustrating the unconformity "U" at both stations. Bunde's three successive heavy mineral zones are correlated with Guenther's three faunal zones (Fu 1, 2, and 3-not shown). To the right are soils dated on Malinche volcano fBO1, 2, 3 (Heine 1978; Pichardo 1999). Units G-I at the cultural site are correlated with Fu2 faunal level at loc. 103 below the unconformity. The Fu2 fossils above the uncon- 
formity can be interpreted as diagenetically redeposited material. Unit E (NW diagonal lines) was characterized by Irwin-Williams (1978:12) as composed of numerous shifting channels, sometimes sandy-silty, sometimes with evidence of arroyo cutting. It is in this unit that the semi-articulated horse and Lerma point were found.

One criticism that has circulated is that too much emphasis has been put on the younger dates from Caulapan since they are associated with only a single artifact, a unifacial scraper comparable to tools below the unconformity at Hueyatlaco. But the same argument must be directed at the single camel pelvis from unit $\mathrm{C}$ and the mastodon molar sample from El Horno which were U-series-dated. Assuming that these dates are as accurate as those from Caulapan, then the proximity of artifacts must be fortuitous. The mastodon molar sample is more problematic since Szabo did not specify whether it consisted of dentine, cement or enamel. Like bone, dentine and cement are more susceptible to uranium contamination from ground water than enamel, which contains less than $1 \%$ organic matter and at least one order of magnitude less uranium (Grun et al. 1987:1023).

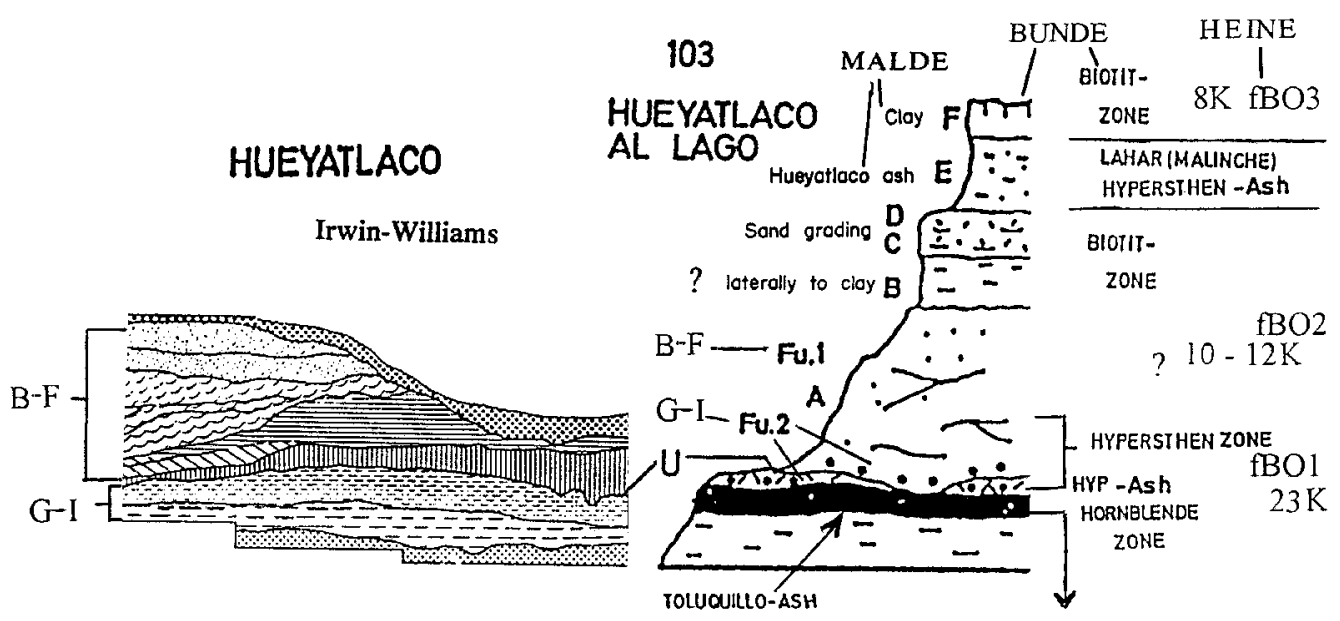

Figure 2 Left, section of Hueyatlaco site adapted from Irwin-Williams 1978, Figure 2. Loc. 103 (Bunde 1973, Figure 13). Stratigraphic data from Malde (in Steen-McIntyre et al. 1981) and Heine 1978. The contact zone between Faunal Zone I (Fu1) and II (Fu2) has not been determined. The Lerma point in Hueyatlaco unit E (NW diagonal lines) may be considered an isochron of the 14-16,000 BP dating for the PWA ash overlying the Lerma point at Iztapan in the Valley of Mexico. See text for discussion.

Tetela Peninsula sites of Hueyatlaco, El Horno and Tecacaxco had a greater risk from ground water contamination since they are located near the base of the Valsequillo Reservoir. The dated North Caulapan site is far upstream and about $6 \mathrm{~km}$ east (cf. map, Figure 1, R14, in Szabo et al. 1969). Since many of the fossils from sites around the Tetela Peninsula were still semi-articulated, and the artifacts are not rolled from transport, it may be assumed that the animals lay where they died and lost skeletal parts to predators and later water flow. But the associated skeletal parts and fragments from other distinct animals must have come from not too distant upstream locations. On-site inspection in 1966 of Hueyatlaco unit I clearly showed that these scattered disarticulated fossils were aligned to the axis of stream flow (Pichardo 1997). The tools were similarly scattered, i.e., beneath the rib of a large ungulate, near a proboscidean acetabulum, and other simple flake scrapers near jaws or ribs (Irwin-Williams 1978:13,17; and personal observation). 


\section{CONCLUSION}

AMS measurement of the poorly preserved Tepexpan fossil indicates contamination at the molecular level (Stafford et al. 1991:54, Figure 6). But mammoth bones from the Valley of Mexico sites may well retain structural collagen and AMS dating would serve as an independent test of the proposed tephra dating. For the Tepexpan fossil the most direct method would be to obtain an ESR date from one of the teeth.

According to Bada (in Steen-McIntyre et al. 1981:7) the degree of permineralization of fossils from the Hueyatlaco site, as well as those found in other Valsequillo localities, excluded the possibility of direct dating of bones by ${ }^{14} \mathrm{C}$ or amino acid racemization. However, the presence of Bison antiquus establishes the existence of at least two chronofaunas; and first hand examination of fossils from different sites shows them to exhibit different degrees of mineralization.

Malde's stratigraphic relations at the Hueyatlaco locality establish the superposition at the Tetela Peninsula. Assuming the U-series dates are correct, the question is whether this low-level in the basin drainage was more subject to ground water contamination than the higher ground around North Caulapan and Totimehuacan. Since only two fossils were dated (camel from Hueyatlaco, mastodon from El Horno) it must be a priority: 1) that many teeth from successive levels (or bone if AMS is utilized) at different sites be dated to determine if they cluster into "old" and "younger" sets; the ESR method has been most effective for dating enamel from the ubiquitous horse and mammoth tooth fragments (Grun et al. 1987), and 2) that it be determined which of the animals at a given level actually represents the kill-the intended prey. Since the Lerma point was associated with the semi-articulated horse, why was this fossil not dated instead of the camel? Both in the Valley of Mexico and of Puebla, the Lerma/El Jobo points predate the Clovis FAD now judged to be about 11,200 BP (Haynes 1993:363-364). The analysis presented here illustrates that the fundamental problem has been one of a lack of interdisciplinary communication.

\section{REFERENCES}

Bunde H. 1973. Geologische untersuchungen im Gebiet des Valsequillo sudlich von Puebla, Mexiko. In Guenther E, editor. Das Mexiko-projekt der Deutschen Forschungsgemeinschaft. Volume 6. Wiesbaden: Franz, Steiner Verlag. p 21-93.

Garcia-Barcena J. 1986. Algunos aspectos cronologicos. In: Lorenzo J, Mirambell L. editors. 35,000 años de historia en el lago de Chalco. Coleccion cientifica 115, ser. Prehistoria. Mexico: Instituto Nacional de Antropologia e Historia. p 219-24.

Graham R. 1978. Biostratigraphy, zoogeography and paleoecology of the late Pleistocene Valsequillo fauna from archeological sites in Puebla, Mexico. Abstract. Papers of the 144th National Meeting of AAA (12-17 February). $160 \mathrm{p}$.

Grun R, Schwarz H, Zymela S. 1987. Electron spin resonance dating of tooth enamel. Canadian Journal of Earth Science 24:1022-37.

Guenther E. 1968. Untersuchungen zur Jungeiszeitlichen und Nacheisseitlichen geologischen und palaontologischen geschichte. Des Mexiko-project der Deutschen Forschungsgemeinschaft. Volume 1. Wiesbaden: Franz, Steiner Verlag. p 32-7.

Guenther E. 1973. Einfuhrung in die Geologischen und palaontologischen untersuchungen im Valsequillo. Das Mexiko-project der Deutschen Forschungsgemeinschaft. Volume 6. Wiesbaden: Franz, Steiner Verlag. p 1-20.

Haynes CV. 1993. Contributions of radiocarbon dating to the geochronology of the peopling of the New World. In: Taylor R, Long A, Kra R, editors. Radiocarbon after four decades: an interdisciplinary perspective. New York: Springer-Verlag. p 355-74.

Haynes CV, Agogino G. 1986. Geochronology of Sandia Cave. Smithsonian contributions to anthropology. Number 32. Washington, DC.

Heine K. 1978. Neue Beobachtungen zur Chronostratigraphie der mittelwisconsinzeitlichen Vergletscherungen und Boden Mexikanischen Vulkans. Eiszeitalter und Gegenwart 28(4):139-47.

Irwin-Williams C. 1978. Summary of archaeological evidence from the Valsequillo region, Puebla, Mexico. In: Browman $\mathrm{D}$, editor. Cultural continuity in Mesoamerica. Chicago: Aldine. p 7-22.

Irwin-Williams C. 1981. Commentary on geologic evidence for age of deposits at Hueyatlaco archaeological site, Valsequillo, Mexico. Quaternary Research 16: 258 . 
Lorenzo J, Mirambell L. 1986. Mamutes excavados en la Cuenca de Mexico (1952-1980). Cuadernos de trabajo 32. Dept. Prehistoria. Mexico: Instituto Nacional de Antropologia e Historia. p 1-151.

Lozano-Garcia M, Ortega-Guerrero B, Caballero-Miranda M, Urrutia-Fucugauchi J. 1993. Late Pleistocene and Holocene paleoenvironments of Chalco Lake, Central Mexico. Quaternary Research 40:332-42.

Mooser F. 1967. Tefracronologia de la Cuenca de Mexico para los ultimos treinta mil años. Boletin 30. Mexico: Instituto Nacional de Antropologia e Historia. p 12-5.

Mooser F, Rul F. 1961. Erupciones volcanicas y el hombre primitivo en la Cuenca de Mexico. Homenaje a Pablo Martinez del Rio. Mexico, DF. p 137-41.

Pichardo M. 1997. Valsequillo biostratigraphy: new evidence for pre-Clovis date. Anthropologischer Anzeiger 55(3/4):233-46.

Pichardo M. 1998. Amerind taxonomy and testable hypotheses. Anthropologischer Anzeiger 56(2): 97-116.

Pichardo M. 1999. Valsequillo Biostratigraphy II: bison, tools, correlate with Tequixquiac. Anthropologischer Anzeiger 57(1):13-24.

Pichardo M, Bonilla J, Hoppe W. 1961. El mamut posiblemente mas antiguo de la Cuenca de Mexico. Homenaje a Pablo Martinez del Rio. Mexico, DF. p113-24.

Stafford T, Hare P, Currie L, Jull A, Donahue D. 1991. Radiocarbon dating at the molecular level. Journal of Archaeological Science 18:35-72.

Stanford D. 1991. Clovis origins and adaptations: an introductory perspective. In: Bonnichsen R, Turnmire $\mathrm{K}$, editors. Clovis origins and adaptations. Corvallis, Oregon: Oregon State University. p 1-13.

Steen-McIntyre V, Fryxell R, Malde H. 1981. Geologic evidence for age of deposits at Hueyatlaco archaeological site, Valsequillo, Mexico. Quaternary Research 16:1-17.

Szabo B, Malde H, Irwin-Williams C. 1969. Dilemma posed by uranium-series dates on archaeologically significant bones from Valsequillo, Puebla, Mexico. Earth and Planetary Science Letters 6:237-44. 